\title{
FIXATION OF AMMONIUM IN FINNISH SOILS
}

\author{
ARMi KaILA \\ University of Helsinki, Department of Agricultural Chemistry
}

Received March 1, 1962

During the last fifteen years the fixation of ammonium ions in a difficultly exchangeable form has been the object of numerous studies in various parts of the world. This phenomenon, analogous to the fixation of potassium ions, has been found to occur in soils containing the clay minerals of the micaceous type, particularly illites and vermiculite. According to the fairly few analyses available, micas and hydrous micas including illites are the main mineral constituents of Finnish clays $(1.10,14,17,18)$, Soveri (18) also found vermiculite in all the samples he investigated. Therefore, it seems probable that the ammonium fixation may play a not insignificant role in our clay soils. This supposition is sustained by the results reported by Swedish authors about the fixation of ammonium and potassium in soils not markedly different from ours $(6,9,12)$. KERÄNEN (10) has shown that our clay soils are able to fix potassium in nonexchangeable form, and in a previous publication (8) some evidence for the fixation of ammonium in our soils was presented.

The work reported in this paper was designed to give an estimate of the ammonium fixing capacity of Finnish soils and to study its dependence on some soil characteristics.

\section{Material and methods}

The material of the present study consisted of 266 soil samples collected from various parts of the country, mainly from cultivated soils. They represented both surface soils down to $15-20 \mathrm{~cm}$ (139 samples) and deeper layers from $20 \mathrm{~cm}$ to $300 \mathrm{~cm}$ (127 samples). The samples were air-dried and ground.

The $\mathrm{pH}$-value of the samples was determined in $0.02 \mathrm{~N} \mathrm{CaCl}_{2}$-suspension in the ratio of 1 to 2,5 . The content of organic carbon was estimated by the method of WALKLEY (19) using the iodometric titration, and the mechanical analysis was performed by the common hydrometer method. 
The fixation of potassium under moist conditions was determined by the method used by Schachtschabel and Köster (16), and the values for exchangeable potassium refer to the results obtained in connection with this determination by the extraction of the untreated samples with $0,5 \mathrm{~N}$ ammonium acetate solution.

The amount of ammonium fixed in a difficultly exchangeable form largely depends on the quantity of ammonium used for the treatment, and on the conditions under which the treatment is performed, e.g. drying, time of contact and temperature $(2,6,12$ etc.). Also the cation of the salt solution used for the removal of the exchangeable ammonium plays an important role $(3,12)$. Thus the ammonium fixing capacity of a soil is a conventional quantity. In this work it was determined by a modification of the method proposed by Schachtschabel (8): $5 \mathrm{~g}$ of soil was shaken in $50 \mathrm{ml}$ of $\mathrm{N} \mathrm{NH}_{4} \mathrm{Cl}$ in a centrifuge tube for one hour in two successive days, centrifuged and washed once with $25 \mathrm{ml}$ of $\mathrm{N} \mathrm{CaCl}_{2}$, then three times with $25 \mathrm{ml}$ of $0.5 \mathrm{~N} \mathrm{CaCl}_{2}$, and once with $25 \mathrm{ml}$ of $0.2 \mathrm{~N} \mathrm{CaCl}_{2}$. Finally, the soil was twice washed with methylated spirits, dried at $105^{\circ} \mathrm{C}$, and ground. $4.0 \mathrm{~g}$ of the treated sample and $4.0 \mathrm{~g}$ of an untreated one, respectively, were boiled in $20 \mathrm{ml}$ of concentrated sulfuric acid for three hours, and the ammonium nitrogen distilled into boric acid. The difference between the $\mathrm{N}$-content in the treated and untreated samples was taken to indicate the ammonium fixing capacity of the soil.

\section{Results and discussion}

The present material is characterized by the following data: a.-values are for the 139 samples of surface soils and b.-values for the 127 samples of deeper layers.

\begin{tabular}{|c|c|c|c|c|c|}
\hline & & minimum & - maximum & mean & s \\
\hline \multirow[t]{2}{*}{$\mathrm{pH}$} & a. & 3.5 & 7.5 & 5.3 & 0.6 \\
\hline & b. & 3.3 & 7.5 & 5.5 & 0.8 \\
\hline \multirow[t]{2}{*}{ Org. C \% } & a. & 0.2 & 10.1 & 3.4 & 1.7 \\
\hline & b. & 0 & 2.9 & 0.6 & 0.5 \\
\hline \multirow[t]{2}{*}{ Clay $\%(<2 \mu)$} & a. & 0 & 72 & 31 & 16 \\
\hline & b. & 4 & 96 & 46 & 24 \\
\hline \multirow[t]{2}{*}{ Exchangeable $\mathrm{K}$ m.e./100g } & a. & 0.08 & 4.53 & 0.51 & 0.46 \\
\hline & b. & 0.09 & 0.95 & 0.41 & 0.22 \\
\hline \multirow[t]{2}{*}{$\mathrm{K}$ fixation m.e./100g } & a. & 0 & 1.27 & 0.38 & 0.19 \\
\hline & b. & 0.06 & 1.80 & 0.78 & 0.51 \\
\hline \multirow[t]{2}{*}{$\mathrm{NH}_{4}-\mathrm{N}$ fixing capacity m.e./100g. } & a. & 0 & 4.0 & 1.0 & 1.0 \\
\hline & b. & 0 & 15.9 & 3.8 & 3.1 \\
\hline
\end{tabular}

It may be seen that these samples represent a fairly large range in the acidity, in the content of organic carbon and in the content of clay. The mean values show the typical differences between the surface soils and the deeper layers. The content of exchangeable potassium varies in the surface soil samples quite markedly, probably owing to the fertilization; yet, the mean value is not far higher than the corresponding figure for the deeper layers.

Attention must be paid to the fact that the data for the "K fixation" do not represent values comparable with the data for $\mathrm{NH}_{4}-\mathrm{N}$ fixing capacity». In the for- 
mer determination, only 2.5 m.e. of $\mathrm{K}$ was added to $100 \mathrm{~g}$ of soil, while the amount of $\mathrm{NH}_{4}-\mathrm{N}$ used for the treatment in the latter determination corresponded to 1000 m.e./100 g of soil. The period of treatment was short, only one hour, in the estimation of the $\mathrm{K}$ fixation, whereas the contact of the soil with the ammonium chloride solution lasted for 24 hours. On the other hand, the removal of the easily exchangeable ammonium ions was more effective than that of the potassium ions.

In the present material the values for the fixation of potassium varies from 0 to 70 per cent of the amount added, and they tend to be lower for the surface soils than for the deeper layers. The fixation seems to be of the same order as in German soils analyzed by the same method (16), particularly, if the fact is taken into consideration that the present material also contained samples with a very low percentage of clay.

The values for " $\mathrm{NH}_{4}-\mathrm{N}$ fixing capacity" are probably close upon the actual maximum fixing capacity of these samples under the moist conditions, since the amount of ammonium nitrogen used for the treatment was fairly high, $140 \mathrm{~g}$ of $\mathrm{N}$ per $1 \mathrm{~kg}$ of soil. Therefore, the percentage of the ammonium fixed cannot be high, while the absolute figures may be marked. Yet, there are samples, both of the surface soils and of the deeper layers in which no fixation of ammonium occurred. On the other hand, some of the subsoil samples showed and exceptionally high fixing capacity, even more than $10 \mathrm{~m} . \mathrm{e} . / 100 \mathrm{~g}$, and also the mean value for the samples from the deeper layers corresponds to more than 3 m.e./100 g. As could be expected, the mean value for the fixing capacity of the surface soils is lower than that of the deeper layers.

From the practical points of view, the ability of the surface soil to fix ammonium nitrogen in difficultly available forms is of more importance than the corresponding phenomenon in the subsoils. If the average fixation in Finnish soils would be 1 m.e./ $100 \mathrm{~g}$, or about $300 \mathrm{~kg} / \mathrm{ha}$ in a layer of $20 \mathrm{~cm}$, the use of ammonium nitrogen fertilizers would not be profitable. Yet, in the practice, the amount of ammonium nitrogen applied as fertilizers will never be as high as 1000 m.e./100 g or about $300000 \mathrm{~kg} / \mathrm{ha}$ mixed in a layer of $20 \mathrm{~cm}$. With lower applications, the relative amount fixed will probably be higher than the average 0.1 per cent of the present material, but the absolute quantities must be far lower. Then also the fact must be taken into consideration that in the field the fertilizers are never mixed so thoroughly that the conditions could correspond to those of the laboratory determination. Further, the use of granulated fertilizers, placement, or surface dressing decrease the amount of soil with which the ammonium ions will get into contact.

In Finland no results of field experiments prove that the fixation of ammonium ions would decrease the effect of ammonium nitrogen fertilizers (8). Also the field experiments performed in Sweden on soils known to be able to fix ammonium ions offer inadequate evidence of the importance of this phenomenon in the practice $(7,13)$.

The ammonium fixation seems to be positively correlated with the potassium fixation, the clay content and the $\mathrm{pH}$ of soil, and negatively correlated with the content of exchangeable potassium, although the correlation is not always close 
(12). In the present material the total linear correlation coefficients between the ammonium fixing capacity and the other characteristics were the following:

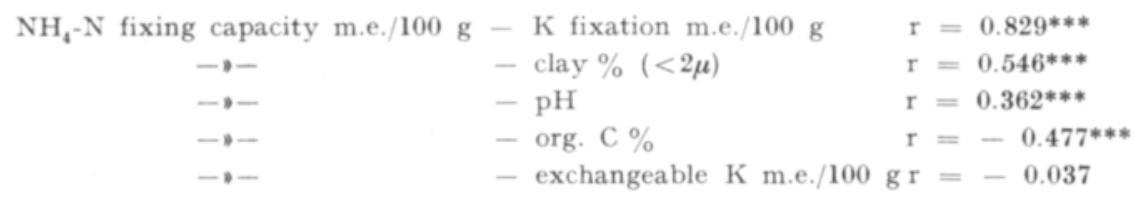

In spite of the essential differences in the determination of the fixation of $\mathrm{NH}_{4}-\mathrm{N}$ and $\mathrm{K}$ there exists a close correlation between these quantities. Also the correlation with clay content is fairly high, that with the $\mathrm{pH}$ values markedly lower. The negative correlation with the content of organic matter is of interest, but it is in accordance with some previous observations on the blocking effect of organic matter on the fixation of ammonium and potassium $(5,11)$, and with the fact that in soils rich in organic matter the ammonium ions released by the ammonification of organic nitrogen compounds have occupied a part of the clay minerals capable of fixing. Also for the samples of the deeper layers the total correlation coefficient between the $\mathrm{NH}_{4}-\mathrm{N}$ fixing capacity and the content of organic carbon is marked: $\mathrm{r}=-0.410^{* * *}$. There seems to be no association between the ammonium fixing capacity and the content of exchangeable potassium in these soils.

Some further information may be obtained by the calculation of the partial correlation coefficients between the ammonium fixing capacity and the content of clay, or $\mathrm{pH}$, or the content of organic $\mathrm{C}$ after the elimination of the effect of the other two quantities. The elimination of the effect of $\mathrm{pH}$ and the content of organic $\mathrm{C}$ lowers the correlation between the ammonium fixing capacity and the content of clay to $r=0.472^{* * *}$. After the elimination of the effect of the clay content and the content of organic $\mathrm{C}$, the correlation between the ammonium fixing capacity and $\mathrm{pH}$ disappears: $\mathrm{r}=0.177$. The partial correlation coefficient between the ammonium fixing capacity and the content of organic $\mathrm{C}$ is $\mathrm{r}=-0.313^{* *}$, after the elimination of the effect of $\mathrm{pH}$ and the clay content.

The partial correlation coefficients separately calculated for the samples from surface soils or from the deeper layers do not significantly differ from the corresponding correlation coefficients for the total material. The multiple correlation coefficients are between 0.6 and 0.7 in all these cases which indicates that the linear regression technique used is fairly well suited for this material.

Since the fixation of ammonium is connected only with certain clay minerals, its association with the total content of clay may not be very close. Only in soils in which the clay fraction consists of the same minerals, this correlation could be expected to be high, a fact emphasized by Schachtschabel (15) in connection with the fixation of potassium.

There is an other factor which must be taken into consideration: the ability to fix ammonium or potassium is not limited to the clay fraction. It has been found that also the fraction between 2 and $20 \mu$ may contain clay minerals capable of fixing (4). Schachtschabel (15) estimates the part played by the coarser fraction to be about 10 per cent of the total fixing capacity of the soil. In the present material 
Table 1. Ammonium fixing capacity in some soil profiles

\begin{tabular}{|c|c|c|c|c|c|c|c|c|}
\hline & \multirow{2}{*}{$\begin{array}{l}\text { Depth } \\
\mathrm{cm} .\end{array}$} & \multirow{2}{*}{$\mathrm{pH}$} & \multirow{2}{*}{$\begin{array}{l}\text { Org. C } \\
\%\end{array}$} & \multicolumn{5}{|c|}{$\begin{array}{c}\text { Particle size fractions, \% } \mathrm{NH}_{4}-\mathrm{N} \text { fixing capacity } \\
\text { m.e. } / 100 \mathrm{~g} \text { of }\end{array}$} \\
\hline & & & & $<2 \mu$ & $2-6 \mu$ & $6-20 \mu$ & soil & clay $<2 \mu$ \\
\hline \multirow[t]{5}{*}{ To 1} & $5-15$ & 4.7 & 1.4 & 11 & 22 & 39 & 1.2 & 10.9 \\
\hline & $20-30$ & 6.2 & 0.5 & 40 & 35 & 22 & 2.5 & 6.2 \\
\hline & $40-50$ & 6.4 & 0.4 & 18 & 32 & 40 & 6.2 & 34.4 \\
\hline & $60-70$ & 6.5 & 0.2 & 21 & 34 & 38 & 6.7 & 31.9 \\
\hline & $200-210$ & 6.7 & 0.1 & 25 & 43 & 30 & 6.2 & 24.8 \\
\hline \multirow[t]{3}{*}{ HP 2} & $0-20$ & 5.8 & 2.2 & 16 & 30 & 38 & 1.6 & 10.0 \\
\hline & $30-40$ & 6.0 & 0.5 & 8 & 28 & 46 & 3.5 & 43.7 \\
\hline & $50-60$ & 6.2 & 0.6 & 17 & 19 & 59 & 5.6 & 33.0 \\
\hline \multirow[t]{3}{*}{ Le 1} & $0-20$ & 5.3 & 5.5 & 32 & 19 & 10 & 1.7 & 5.3 \\
\hline & $45-60$ & 5.7 & 0.6 & 70 & 10 & 7 & 5.0 & 7.1 \\
\hline & $95-105$ & 6.3 & 0.3 & 40 & 32 & 22 & 10.6 & 26.5 \\
\hline \multirow[t]{4}{*}{ H 3} & $0-10$ & 5.9 & 2.3 & 53 & 13 & 13 & 2.3 & 4.3 \\
\hline & $20-30$ & 5.8 & 0.7 & 75 & 12 & 5 & 6.3 & 8.4 \\
\hline & $40-50$ & 6.1 & 0.5 & 86 & 8 & 10 & 7.1 & 8.3 \\
\hline & $60-70$ & 6.3 & 0.4 & 92 & 4 & 2 & 7.6 & 8.3 \\
\hline \multirow[t]{3}{*}{ U1 } & $0-20$ & 4.7 & 3.4 & 65 & 15 & 10 & 2.4 & 3.7 \\
\hline & $20-30$ & 4.6 & 0.9 & 68 & 18 & 6 & 2.1 & 3.1 \\
\hline & $50-60$ & 5.4 & 0.4 & 57 & 13 & 12 & 4.6 & 8.1 \\
\hline \multirow[t]{3}{*}{$\mathrm{Ua}$} & $0-20$ & 6.0 & 3.2 & 56 & 14 & 12 & 3.4 & 6.1 \\
\hline & $20-30$ & 5.8 & 1.7 & 66 & 16 & 7 & 4.2 & 6.3 \\
\hline & $50-60$ & 5.7 & 0.6 & 70 & 14 & 12 & 5.8 & 8.3 \\
\hline
\end{tabular}

no correlation could be found between the ammonium fixing capacity and the silt fraction, yet, in some soils the latter seems to be of importance. This may be seen from the data in Table 1.

In the profile To 1 , the clay content is fairly low, except in the layer from 20 to $30 \mathrm{~cm}$. Yet, in the deeper layers the ammonium fixing capacity is high, more than 6 m.e. $/ 100 \mathrm{~g}$ of soil. If this capacity is calculated as m.e./100 $\mathrm{g}$ of clay, the figures obtained are extremely high, from 25 to 35 m.e. On the other hand, these samples are rich in silt which in these parts of our country with the bedrock of mica-schist (Tohmajärvi, Eastern Finland) is known to contain more mica and illite than do the clays from the granitic areas (18). Therefore, it seems possible that a large part of the ammonium fixing capacity in these deeper layers may be attributed to the silt fraction. Probably the silt fraction also plays an important role in the soil HP 2 where particularly the layer from 30 to $40 \mathrm{~cm}$ has, in spite of a very low clay content, a fairly marked fixing capacity. This sample originates from Laukaa, Central Finland. Also in the soil Le 1 from Leteensuo, Southern Finland, the high fixing capacity in the deepest layer may be partly connected with the silt fraction. Further evidence, of course, is needed, before these assumptions are proved to be valid. 
The ammonium fixing capacity expressed as m.e./100 $\mathrm{g}$ of clay varied in the present material from 0 to 44 m.e. with an average of 6 m.e. In the typical clay soil H 3 from Jokioinen, Southern Finland (Table 1), the fixing capacity is almost equal in the three layers from 20 to $70 \mathrm{~cm}$, or about $8.3 \mathrm{~m}$.e. $/ 100 \mathrm{~g}$ of clay. In the surface layer, the fixing capacity of clay is only about one half of that in the deeper layers. This quite typical fact may be explained on the basis of a higher content of organic matter and its several effects.

The effect of the acidity of the clay soil is illustrated by the data for the samples $\mathrm{Ul}$ and Ua, both of which originates from the same parish, Uskela in Southwest Finland (Table 1). The former is a Litorina clay soil, the latter a typical Glacial clay soil. In the layers down to $30 \mathrm{~cm}$, the ammonium fixing capacity is in the Glacial soil almost twice as high as in the Litorina soil, both when expressed as m.e. $/ 100 \mathrm{~g}$ of clay and of soil. In the layer from 50 to $60 \mathrm{~cm}$ the difference between the clays is no more marked, probably, because they are of the same material.

\section{Summary and conclusions}

The ammonium fixing capacity of Finnish soils was studied by analysing a material of 139 samples from surface soils and 127 samples of deeper layers collected mainly from cultivated soils from various parts of the country. The $\mathrm{pH}$-values of these samples measured in $0.02 \mathrm{~N} \mathrm{CaCl}_{2}$-suspension ranged from 3.3 to 7.5 , the content of organic $\mathrm{C}$ from 0 to 10.1 per cent, and the content of clay $(<2 \mu)$ from 0 to 96 per cent.

The ammonium fixing capacity was determined under moist conditions by treating the samples for 24 hours with $\mathrm{N} \mathrm{NH}_{4} \mathrm{Cl}$ solution corresponding to 1000 m.e. of $\mathrm{NH}_{4}-\mathrm{N}$ per $100 \mathrm{~g}$ of soil, and removing the easily exchangeable ions by washing with $\mathrm{CaCl}_{2}$-solutions. The difference in the nitrogen content of treated and untreated samples determined by digesting in concentrated sulfuric acid, was taken to indicate the amount fixed under these conditions. The results varied from 0 to 4.0 m.e. $/ 100 \mathrm{~g}$ of soil in the surface samples, and from 0 to 15.9 m.e. $/ 100 \mathrm{~g}$ of the soils from the deeper layers. The corresponding mean values were 1.0 and 3.8 m.e. per $100 \mathrm{~g}$ of soil, respectively.

The association of the ammonium fixing capacity (1) with the clay content (2), $\mathrm{pH}(3)$, and the content of organic C (4) of the samples could be characterized by the following partial linear correlation coefficients:

$$
\mathrm{r}_{12 ; 34}=0.472^{* * *} \mathrm{r}_{13 ; 24}=0.177 \quad \mathrm{r}_{14 ; 23}=-0.313^{* *}
$$

The total linear correlation coefficient between the ammonium fixing capacity and the fixation of potassium under moist conditions ( 2.5 m.e. of $\mathrm{K}$ added to $100 \mathrm{~g}$ of soil) was $\mathrm{r}=0.829^{* * *}$. No correlation existed between the ammonium fixing capacity and the content of exchangeable potassium in these samples.

Some of the results point to the possibility that in certain soils the coarser fractions, from 2 to $6 \mu$, or even from 6 to $20 \mu$, may play an important role in the fixing of ammonium in difficultly exchangeable form.

In spite of the fact that under laboratory conditions the ammonium fixing capacity of Finnish soils may be fairly high, even in the surface soils, the conclusion 
was drawn that usually under the field conditions, the fixation of ammonium ions in difficultly exchangeable form might not reduce the effect of ammonium nitrogen fertilizers to any marked degree.

\section{R E F E R E N C E S:}

(1) Aarnio, B. 1942. Ueber die Tone Finnlands und ihre Eigenschaften II. Agrogeol. Julk. No 53. Helsinki.

(2) Allison, F. E. \& Doetsch, J. H. \& Roller, E. M. 1951. Ammonium fixation and availability in Harpster clay loam. Soil Sci. 72: 187-200.

(3) Allison, F. E. \& Kefauver, M. \& Roller, E. M. 1953. Ammonium fixation in soils. Soil Sci. Sos. Amer. Proc. 17: 107-110.

(4) Barshad, I. 1951. Cation exchange in soils I. Soil Sci. 72: 361-371.

(5) Ghildyal, B. P. \& Singh, P. N. 1961. Ammonium fixation in cultivated and afforested alluvial soil. Soil and Plant Food 6: 164-169.

(6) Jansson, S. L. 1958. Tracer studies on nitrogen transformations in soil with special attention to mineralisation-immobilization relationships. Ann. Roy. Agr. Coll. Sweden 24: 101-361.

(7) - - \& ERIcsson, J. 1961. Kväve- och kaliumproblem i skånsk växtodling. Socker, Handl. I, 17: $2: 9-21$.

(8) Kaila, A. \& Hänninen, P. 1961. Fertilizer nitrogen in soil. J. Sci. Agric. Soc. Finland 33 : $169-184$.

(9) Karlsson, N. 1952. Kalium i marken. Kungl. Lantbr. Akad. Tidskr. 91: 297-329.

(10) KERÄnen, T. 1946. Kaliumista Suomen maalajeissa. (On potassium in Finnish soils.) Acta Agr. Fennica 63.

(11) Mortland, M. M. 1961. Influence of some organic salts on the absorption of potassium by vermiculite. Nature 192: $481-482$.

(12) Nöммıк, H. 1957. Fixation and defixation of ammonium in soils. Acta Agr. Scand. 7: $395-436$.

(13) - 1961. Kalium- und Ammoniumfixierung in schwedischen Ackerböden. Kungl. Lantbr. Akad. Tidskr., Suppl. 5: 28-39.

(14) Salminen, A. 1939. Suomalaisten savien kivennäiskokoomuksesta. (On the mineral composition of Finnish clays.) Suomen Kemistilehti A 12: 2-7.

(15) SснаснтsснавеL, P. 1961. Fixierung und Nachlieferung von Kalium- und Ammonium-Ionen. Landw. Forsch. 15. Sonderh. 29-47.

(16) - - \& Köster, W. 1960. Chemische Untersuchungen an Marschen II. 3. Zeitschr. Pflanzenern. Düng., Bodenk. 89: 148-159.

(17) Soveri, U. 1950. Differential thermal analyses of some Quarternary clays of Fennoscandia. Ann. Acad. Scient. Fenn. A III. 23.

(18) - 1956. The mineralogical composition of argillaceous sediments of Finland. Ibid 48.

(19) WALKLEY, A. 1935. An examination of methods for determining organic carbon and nitrogen in soils. J. Agr. Sci. 25: 598-609.

S E L O S T S:

AMMONIUMTYPEN PIDÄTTYMISESTÄ VAIKEASTI VAIHTUVAKSI MAISSAMME

Armi KaILA

Yliopiston maanviljelyskemian laitos, Helsinki

Maittemme kykyä pidättää ammoniumtyppeä vaikeasti vaihtuvaan muotoon tutkittiin analysoimalla 139 pintanäytettä ja 127 näytettä syvemmistä kerroksista. Näyteaineisto oli kerätty maamme eri osista ja se edusti happamuudeltaan, orgaanisen hiilen ja saveksen pitoisuudeltaan verraten laajaa asteikkoa. Ammoniumtypen pidätyskapasiteetin määrittämiseksi kehitettiin ScHAcHTSCHABELin ehdottamasta menetelmästä sopiva muunnos. 
Kun maanäytteitä käsiteltiin $\mathrm{NH}_{4} \mathrm{Cl}$-liuoksella (1000 me. $\mathrm{NH}_{4}-\mathrm{N} / 100 \mathrm{~g}$ maata) kuivattamatta ja kuumentamatta ja helposti vaihtuva ammonium poistettiin pesemällä $\mathrm{CaCl}_{2}$-liuoksella, saatiin ammoniumin pidätyskapasiteetiksi arvot, jotka vaihtelivat $0-4.0 \mathrm{me} . / 100 \mathrm{~g}$ maata pintanäytteissä ja 0-15.9 me./100 g maata syvempien kerrosten näytteissä; vastaavat keskiarvot olivat 1.0 ja $3.8 \mathrm{me} . / 100 \mathrm{~g}$.

Ammoniumin pidätyskapasiteetti oli riippumaton näytteen happamuudesta, kun saveksen ja orgaanisen hiilen pitoisuuden vaikutus eliminointiin. Sen sijaan ammoniumin pidätyskapasiteetin ja saveksen pitoisuuden välinen korrelaatio säilyi verraten korkeana, vaikka happamuuden ja orgaanisen hiilen pitoisuuden vaikutus eliminointiin $\left(r=0.472^{* *}\right)$. Ammoniumin pidätyskapasiteetin ja orgaanisen hiilen pitoisuuden välinen matalahko negatiivinen korrelaatio säilyi molempien muiden tekijöiden eliminoimisen jälkeen $\left(\mathrm{r}=-0.313^{* *}\right)$.

Eräăt tulokset näyttivät viittaavan siihen, että ainakin joissakin maissa myös karkeammat fraktiot, $2-6 \mu$ ja mahdollisesti myös $6-20 \mu$, osallistuvat ammoniumin pidättämiseen vaihtumattomaan muotoon.

Huolimatta siitä, että laboratorion olosuhteissa saatiin varsin korkeita arvoja osoittamaan ammoniumin pidätyksen kapasiteettia, pääteltiin, ettei ammoniumin pidätys yleensã vaikuttane ammoniumtyppilannoitteiden tehoon maissamme: Käytännön olosuhteissa annettavat ammoniumtypen määrät eivät ole kuin murto-osa laboratoriomäärityksessä käytetystä. Typpilannoitteiden ammoniumionit eivät myöskään kentällä joudu maan pidättävien tekijöiden kanssa läheskään yhtă tehokkaaseen kosketukseen kuin määrityksessä. 